\title{
REINFORCEMENT TOOL OF WHISTLEBLOWING TO ERADICATE FRAUD IN PUBLIC SECTOR
}

\author{
Siti Aisyah Basri*1, Ahmad Daud Marsam, Rozaiha Ab Majid', Nor 'Asyiqin Abu', \\ Nafsiah Mohamed ${ }^{2}$ \\ Faculty of Accountancy, Universiti Teknologi MARA Melakal, Accounting Research Institute, \\ Universiti Teknologi MARA Malaysia ${ }^{2}$
}

\begin{abstract}
Whistleblowing is an internal control system that be a way to reduce or eradicate fraud. This paper focuses on investigating the reasons for whistleblowing is not a preferred method to eradicate fraud. This paper starts with defining the term "whistleblowing". In its simplest form, whistleblowing involves the act of reporting improper conduct within an organisation to internal or external parties. This paper explains the issues and effects concerning whistleblowing. One of the issues is the violation of public trust. Lastly, this paper will describe the reasons for resistance of people to blow the whistle. Among the reasons is the fear of reprisal. This is a concept paper and it aims to conduct interview session with the Head for every local authority in Melaka. The findings of this paper can be used by the Government to create a new model related to whistleblowing to eradicate fraud in public sector. The Government could use this paper as the support to enhance the achievement of National Key Result Areas (NKRAs) Against Corruption.
\end{abstract}

Keywords: Whistleblowing, Public Sector

\section{INTRODUCTION}

The increasing numbers of fraud cases is becoming a burden to the local authorities in Malaysia. There are many types of fraud such as corruption, bribery and misappropriation of assets. Eaton and Akers (2007) states that problems actually exist in the government and nonprofit sectors and not only in the corporate sector. Recent alleged problems include kickbacks, payoffs, bribery, embezzlement and collusive bidding.

Rozaiha, Nafsiah, Azizah and Zanariah (2010) concludes that there is a risk of misappropriation of assets occurring in local government authorities in Malaysia. The misappropriation of assets could significantly affect the finance of the local authorities. Future misappropriation should be ceased to happen if strict internal control is to be implemented within the local authorities.

According Tan and Ong (2011), whistleblowing is one of the mechanism for internal control system. The study claims that whistleblowing should be adopted by both public and private sectors to achieve good corporate governance practices. University's graduates should be prepared to face challenges in the accounting profession and this could be done through the inculcation of the strong ethical sense and critical thinking skill (Nur Barizah, Suhaiza and Suaniza, 2008). Similarly, both academic and non-academic staffs should also be equipped 
with these skills. This is essential to prepare them to be able to make judgement on the situation and time that requires whistleblowing.

Whistleblowing is an internal control system that can be seen as a way to reduce or may eliminate the misappropriation of assets. Organisations are encouraged to develop whistleblowing policies because they are seen as part of their internal control (Brennan and Kelly, 2007). Whistleblowing protects society from any corporate behaviour that could result from companies' irresponsible action (Hazlina, 2011). It is very unlikely that employees will blow the whistle if they do not have any knowledge on whistleblowing. Some of them might have a certain level of understanding on what whistleblowing is, however, they might be afraid that if they whistleblow, they are not well-protected.

The 2014 Malaysian Anti-Corruption Commission (MACC) has clearly indicated the connection between whistleblowing and National Key Result Area (NKRA). In order to obtain the status of a developed country, the economy of this country must be stable. The country needs to have the trust from foreign investors to achieve economic stability. Therefore, it is crucial to have a good image in the eyes of those investors. NKRA Against Corruption is tasked to look into the matter and to ensure clean and transparent business in the public and private sectors. Hence, eventually the whistleblowing is in need to achieve NKRA Against Corruption.

However, people are still afraid and refuse to whistleblow (Tan \& Ong, 2011). The reasons of this resistance to whistleblow should be investigated because the resistance could prevent the success of NKRA Against Corruption. This research suggests to fight the corruption by reinforcing whistleblowing.

\section{What is whistleblowing?}

Near and Miceli (1985) defines whistleblowing as the disclosure by former or current organisation members of illegal, immoral or illegitimate practices under the control of their employers, to persons or organisations that may be able to affect action.

Whistleblower Protection Act (WPA) 2010 defines “whistleblower” as:

"Any person who makes a disclosure of improper conduct to the enforcement agency under Section 6".

The WPA 2010 further defines "improper conduct" as any conduct which if proved, constitutes a disciplinary offence or a criminal offence.

Whistleblowing involves the act of reporting improper misconduct within an organization to internal or external parties.

According to Hazlina (2011), whistleblowing is an act of an informant who exposes wrongdoing within an organization with the aim to stop the wrongdoing. A whistleblower will report the wrongdoing to proper medium and authorities that have the power and are presumed willing to take corrective actions. The wrongdoings include any kind of violation of law, rules and regulation such as fraud and corruption. 
If the whistleblowing policies and procedures are implemented successfully in an organisation, it would be a good early warning system to the organisation to eliminate improper conduct before the matter becomes worse and worst (Tan \& Ong, 2011).

Francis, Armstrong and Foxley (2015) states that the purposes of whistleblowing include to expose wrongdoing, to stop wrongdoing, to prevent wrongdoing and to defend one's position. Eventually, whistleblowing aims to reduce corruption, to save money and to prevent problems associated with the wrongdoing.

\section{The issues and effects concerning whistleblowing}

Misconduct in an organisation is associated with declining organisational performance and it concerns with the issues that affect the society as a whole. These issues include issues related to public safety and/or purported violation of public trust. Francis et al (2015) states whistleblowing need to be conducted because wrongdoing may violate the personal and/or corporate financial gain, danger to the public, danger to someone and abuse of authority.

Therefore, whistleblowing is seen as a method to reduce the negative effect and issues of the misconduct. According to Near and Miceli (1985), the whistleblower may provide valuable information that is very helpful in improving organization effectiveness. This is supported by Lewis (2005) which concludes that there is an emerging concept of having whistleblowing as public interest reporting. Besides that, Hazlina (2011) believes that whistleblowing promotes good corporate governance and accountability in a corporation.

Malaysia is in the journey of becoming a developed country as a high-income nation by 2020 , thus the Government has introduced the 6 NKRAs as a support. In order to achieve this vision, it is crucial to have stable economy with zero corruption to eventually have the foreign trust to invest in Malaysia. The foreign investment contributes significant effect on the economy of a country. Thus, obtaining this foreign trust is a must. Hence, reinforcing whistleblowing could be seen as one of the way to eliminate fraud in the public sector. Whistleblowing is a crucial method to support the NKRA Against Corruption and eventually to eradicate fraud in public sector.

\section{The resistance to whistleblow}

Whistleblowing is not as simple as it sounds. Despite the benefits of whistleblowing in detecting and preventing improper conduct, not many are willing to whistleblow on their employers' wrongdoing (Tan \& Ong, 2011). Their unwillingness might be due to the perception that whistleblowing may result in loss of career, loss of family and social life. Whistleblowers might feel in danger and often whistleblowing requires exceptional courage.

O'Leary and Cotter (2000) finds that becoming a whistleblower is still perceived as unacceptable. It appears as if whistleblowing on the employers is still unacceptable but whistleblowing on a friend is almost inconceivable. Employees would not blow the whistle because they are afraid of reprisals.

Many potential whistleblowers are not confident that they will get statutory protection from employment tribunals and the courts under Part IV A Employment Rights Act 1996 (Lewis, 2005). Besides that, organisation may encourage the internal reporting of concerns about wrongdoing that do not have a public dimension to further its private interest. 
A study by Brennan and Kelly (2007) finds that trainee auditors in organisations that have adequate formal structures for whistleblowing have greater confidence that by whistleblowing internally their careers would not be adversely affected. At the same time, trainee auditors showed a reluctance to whistleblow externally. The trainee auditors also expressed little confidence in the protection offered by legislation for whistleblowers.

A study done by Nur Barizah et al (2008) has shown that $60 \%$ of the respondents indicated that they will not whistleblow regardless realising the act is unethical. Fortunately, $37.6 \%$ of the respondents indicated that they will take immediate action by informing the relevant corporate authorities regarding the unethical act.

Nur Barizah et al (2008) claims that people are not willing to whistleblow because they are still worried about the lack of protection if they whistleblow. Other than that, the resistance might be due to the perception of others on the whistleblower. In most cases, the whistleblower may find themselves isolated from the others. This might be very difficult especially loyalty is a very strong trait in the Asian culture. Whistleblower might contemplate between acting for the society as a whole or conforming to being loyal to the management and to their corporate leaders. When there is a possibility that necessary action will be taken on the wrongdoers, the percentage of the respondents who were willing to whistleblow has increased to $44 \%$. This shows that the existence of laws, rules and regulations may help build the confidence in the people who intend to whistleblow.

The same finding has been found by a study by Rafik (2008) that claims the respondents generally felt that whistleblowing was necessary in cases of fraud, although they were slightly less likely to do it themselves. This might be due to the high costs involved such as a retaliation and the difficulty to find future job in the same profession. Other than that, Francis et al (2015) found that people are not willing to whistleblow because they believe that no action will be taken, fear of retaliation and loss of the means of livelihood.

Soni, Maroun and Padia (2015) finds that higher level of distributive justice, interactional justice and procedural justice tend to increase the propensity to whistleblow. Distributive justice refers to the perceived fairness of outcomes. Interactional justice focusses on how the employee perceive his interactions with his superior. Procedural justice refers to the perceived fairness of the processes followed to achieve those outcomes. On the other hand, age, gender, seniority, performance evaluation and religiosity do not have a significant effect on decision to whistleblow. However, this is not in line with the previous study by Brennan and Kelly (2007) which finds that as the trainee auditors progress in their careers they become less reluctant to whistleblow externally.

In order to encourage Malaysian to whistleblow, the Parliament has passed WPA 2010. WPA 2010 intends to combat corruption and other wrongdoings by encouraging and facilitating disclosures of improper conduct in the public and private sector. The purpose of this Act is also to protect persons making those disclosures from unfavourable action, to provide for the matter disclosed to be investigated and dealt with and to provide for the remedies connected therewith. 


\section{PROSPECTIVE RESEARCH METHODOLOGY}

The research is a qualitative research. It focuses on the local authorities in Melaka, namely Majlis Bandaraya Melaka Bersejarah (MBMB), Majlis Perbandaran Alor Gajah (MPAG), Majlis Perbandaran Jasin (MPJ) and Majlis Perbandaran Hang Tuah Jaya (MPHTJ).

An interview will be held with the Head for every local authority. The interview will focus on the examination of whistleblowing policies and procedure implemented by the Government to eradicate fraud in public sector in their local authorities.

The content of the interview will be organised and analysed using NVivo 10 for Windows.

\section{CONCLUSION}

Those at the managerial or executive level hold the key to the companies' success and ironically, most of corporate misconduct is done by those at these levels. Hence, it is very crucial to have ethical work environment by reinforcing whistleblowing.

The WPA 2010 came into force on $15^{\text {th }}$ December 2010. However, there is still a bridging gap between whistleblower protection and good governance practices in Malaysia. As mentioned earlier, people have little confidence in the protection offered by legislation. Government has the vital role to create conducive condition for whistleblowers. If this does not happen, the Government might have problems to achieve successfully NKRA Against Corruption. The Government could use this research as the support to enhance the achievement of NKRA Against Corruption.

\section{ACKNOWLEDGEMENT}

The authors are grateful to the management of Universiti Teknologi MARA (UiTM), Accounting Research Institute (ARI) and Fundamental Research Grant Scheme (FRGS) by Ministry of Higher Education, Malaysia for their beliefs and continuous support.

\section{REFERENCES}

Brennan, N. and Kelly, J. (2007). A Study of Whistleblowing among Trainee Auditors. The British Accounting Review, Vol. 39, pp. $61-87$

Eaton, T. V. and Akers, M. D. (2007). Whistleblowing and Good Governance. The CPA Journal, June 2007, Vol. 77, pp. $66-71$

Francis, R.D., Armstrong, A. F. and Foxley, I. (2015). Whistleblowing: A Three Part View. Journal of Financial Crime, Vol. 22, Issue 2, pp. -

Hazlina, S. M. N. A. (2011). Whistleblowing and Corporate Social Responsibility. SEGi Review, Vol. 4, No. 2 pp $58-66$ 
Lewis, D. (2015). Is a public interest test for workplace whistleblowing in society's interest? International Journal of Law and Management, Vol. 57, No. 2, pp. $144-158$

Malaysian Anti-Corruption Commission (2014) website retrieved on $10^{\text {th }}$ May 2015 from http://www.sprm.gov.my/index.php/en/

Near, J. P. and Miceli, M. P. (1985). Organisational Dissidence: The Case of Whistleblowing. Journal of Business Ethics, Vol. 4, No. 1, pp 1 - 16

Nur Barizah, A. B., Suhaiza, I. and Suaniza, M. (2008). Ethics of Future Accounting Professionals: Evidence from Malaysia. Journal of Financial Reporting and Accounting, Vol. 6, pp $21-23$

O'Leary, C. and Cotter, D. (2000). The Ethics of Final Year Accountancy Students: An International Comparison.d Management Auditing Journal, 15(3), pp. 108 - 115

Rafik, E. (2008). Auditing Students' Professional Commitment and Anticipatory Socialization and their Relationship to Whistleblowing. Managerial Auditing Journal, Vol. 23, Issue 3, pp $283-294$

Rozaiha, A. M., Nafsiah, M., Azizah, A. and Zanariah, M. (2010). An Exploratory Study on the Possibility of Misappropriation of Assets occurring in a Local Authority. International Conference on Science and Social Research (CSSR) 2010, Kuala Lumpur, Malaysia

Soni, F., Maroun, W. and Padia, N. (2015). Perceptions of Justice as a Catalyst for Whistleblowing by Trainee Auditors in South Africa. Meditari Accountancy Research. Vol. 23, No. 1, pp $118-140$

Tan, P. M. and Ong, S. F. (2011). Comparative Analysis of Whistleblower Protection Legislations in England, USA and Malaysia. African Journal of Business Management, Vol. 5, No. 26, pp $10446-10455$

Whistleblower Protection Act 2010 